\title{
New Normal: What Ulama Can Do as a Norm Entrepreneur
}

\author{
Inda Mustika Permata ${ }^{1, *}$ Bima Jon Nanda ${ }^{1,}$ Rifki Dermawan ${ }^{1}$ \\ ${ }^{I}$ Department of International Relations, Social and Political Sciences Faculty, Universitas Andalas \\ ${ }^{*}$ Corresponding author. Email: indamustikapermata@soc.unand.ac.id
}

\begin{abstract}
This research attempts to examine the role of Ulama as a norm entrepreneur in the adaptation of the new normal in West Sumatra. West Sumatra is one of the fifteen provinces in Indonesia with the highest number of Covid-19 cases. In the past week, West Sumatra was one of the five provinces where the number of Covid-19 cases increased significantly. With this number, we need to optimize the adaptation of the WHO's norm in West Sumatra. With the majority of the population being Muslim, West Sumatra has an influential Islamic identity. The religious character of society opens up space for Ulama to play a role in performing the adaptation of the new normal to cope with the spread of Covid-19. The norms originate globally, in order to be applied must be localized. The method applied in this research is a qualitative method using secondary and primary data. Norm entrepreneur and norm localization employed in this research as the concept. The result shows that in optimizing the adaptation of a new order in West Sumatra, Ulama frames the idea of a new normal using the hadith and verses of the Koran. The new normal norm reconstructed and linked to the existing values in West Sumatra. This idea persuaded through discourses delivered in public spaces. It easier for Ulama as local actors with a reputation in West Sumatra to localize norms originating from WHO.
\end{abstract}

Keywords: Ulama, New Normal, Localization, Adaptation

\section{INTRODUCTION}

The President of Indonesia officially declared the Covid-19 outbreak as a national disaster [1]. Responding to this case, many areas in Indonesia, including West Sumatra, have implemented Large-Scale Social Restrictions since 22 April 2020 with the approval of the Indonesian Minister of Health. After two months, 8 June 2020, West Sumatra then implemented a new normal adaptation. The new order, based on the explanation of the Chairperson of the Task Force for the Acceleration of Covid-19 Handling, Wiku Adisasmita, is a behaviour change to continue carrying out everyday activities. However, implementing health protocols to prevent Covid-19 transmission add in this change. The health protocol in question is maintaining social distancing by reducing physical contact, using masks, and maintaining cleanliness and a healthy lifestyle [2]

West Sumatra is one of the provinces affected by the Covid-19 pandemic, until 12 October 2020, there have been 8,874 positive cases of Covid-19 [3]. The West Sumatra region itself is an area with a majority of the population being Muslim and has a strong Islamic identity [4]. This identity notice from the philosophy of the Minangkabau people, namely the Adat Basandi Syarak, Syarak Basandi Kitabullah (adat based on religion, a religion based on the Koran). The religious character of the people of West Sumatra will open up space for Ulama to play a significant role in implementing the adaptation of the new order to cope with the spread of Covid-19. The role of Ulama is essential because of their position in the society of West Sumatra. For Minangnese (native West Sumatra residents), Surau or Mushalla as a place for Muslim youth to learn and interact socially. Not only that, through the "Oath of Sati Marapalam" it is said that the Minangnese are Muslims. They characterize with three principal characteristics, strong adherence to Islam, adherence to the matrilineal system, a strong tendency to migrate or migrate [5]. Furthermore, for the Minangnese, there is a division of authority, namely, 
political authority by the king (leader), customary authority by the penghulu, and religious authority by Ulama. So for the people of West Sumatra, the Ulama is an important figure, because they are the leaders of the Islamic religion, the religion that characterizes the Minangnese. Therefore, it is crucial to examine the role of Ulama in implementing the adaptation of the new normal norm. It is because even though WHO has provided guidelines in living life during the pandemic, in its application in society, local values need to be used to apply global norms.

\section{METHOD}

This research uses a qualitative method. The data used in this research are primary and secondary. We gather primary data from interviews with representatives of the Indonesian Ulama Council (MUI), Muhammadiyah, Nahdlatul Ulama in West Sumatra. Then the survey results were filled in by 323 respondents from West Sumatra. Meanwhile, secondary data obtained from journal articles, books, reports, and news based on keywords such as new normal, West Sumatra, Covid19, Policies, and Ulama. After the data was collected, data triangulation was then carried out, namely by comparing the data obtained from interviews, report documents, books, and journal articles used. The data is then analyzed using a conceptual framework of norm entrepreneur and norm localization. After that, we can conclude that the role of Ulama could play in preventing the spread of Covid-19 in new normal conditions.

\section{NEW NORMAL ADAPTATION IN WEST SUMATRA}

In the process, West Sumatra has undergone three stages of Large - Scale Social Restriction. This stage, according to Irwan Prayitno, the Governor of West Sumatra, has the first objective, to prepare West Sumatra for the adaptation of a new habits. Then the second, disciplining the public to follow health protocols, third, maximizing the health system, such as hospitals, laboratories, and all equipment related to handling the Covid-19 [6]. On June 8, 2020, West Sumatra officially began implementing the new normal. This term conveyed by WHO Director-General, Dr Tedros, that the world is still in a long process of finding vaccines and drugs so that this virus will coexist with us. He also said that all countries must have the same public health measure in dealing with this pandemic, namely, find every case; isolation of each case; test each case; handle every case, trace and quarantine every contact; educate, assist, and empower the entire community [7]. These six things are the basis for the country's response to the Covid-19 pandemic.

Referring to the WHO document on the Covid Strategy Update, health steps to reduce transmission that can be taken, namely first, personal actions that can reduce transmission such as washing hands, maintaining distance, using masks, and respiratory etiquette. Second, actions at the community level, such as suspending mass gatherings, reducing public transportation, closing nonessential places of work and education. Third, measures to reduce the risk of importation or reintroduction of viruses from areas of high infection, such as limiting national and international travel, increasing screening and quarantine. Fourth, measures to ensure protection for vulnerable groups and medical personnel. The above steps are a series of health protocol norms that must be followed. The Government of West Sumatra is trying to adapt these four things.

In maximizing the implementation of the new normal, the government has appealed to the public. However, this effort has not been significant due to the increasing number of cases of Covid-19 sufferers in West Sumatra. Referring to the West Sumatra covid-19 information site, the number of positive cases when the new normal officially implemented (June 8, 2020) was 199 cases. Meanwhile, the latest data (October 13, 2020) has become 3716 positive cases [8]. The data shows that there is a vast difference in numbers between before and after the new normal applied. The reason for this high number is the lack of public awareness regarding adherence to health protocols. Brian Sriphastuti, a Main Expert at the Presidential Staff Office, said that the public focused on the word "normal" in new normal, which thinks that conditions have returned to what they were before pandemic [9]. As a result, according to Brian, many people ignore health protocols, especially when they are in public space. Departing from this, the government uses the term new habitual adaptation to replace the term new normal [10]. The goal is to make people more aware and adapt their habits to the health protocols disseminated by WHO.

In order to encourage the effectiveness of implementing health protocols in everyday life, the West Sumatra DPRD has ratified Regional Regulation No. 6 of 2020 concerning Adaptation of New Habits (IMR) in the Prevention and Control of the Covid-19 Virus on September 11, 2020. Through this regulation, adaptation of new habits norms or new normal are given binding legal force in them. Therefore, individuals who violate health protocol rules may be subject to administrative or criminal sanctions. The regulation aims to reduce the rate of positive cases of Covid-19 in West Sumatra. This effort shows that the government is serious about adopting the new normal in West Sumatra.

\section{WEST SUMATRAN PEOPLE'S PERCEPTION ABOUT ULAMA}

Islam is the religion with the largest number of adherents in West Sumatra, namely $98.02 \%$ of the total 
population of this province [11]. In various districts and cities, the values of local wisdom are strongly influenced by the religious element of Islam and the central role of Ulama, for example in Ulakan village, Padang Pariaman, aspects of religiosity are closely related to disaster issues [12]. In general, the Minangkabau culture carried out by the people of West Sumatra places the position of the Ulama as a central figure in social life. This idea is in line with the perception of $94.8 \%$ of respondents who agree that Ulama is important figures in West Sumatra.

According to Madrasah Tarbiyah Islamiyah, a model for Islamic education institutions in West Sumatra, Ulama have various roles. They are not only educators at the institutional level but develop religious functions in the community [13]. This position further emphasizes the influence of the Ulama in the life of the people of West Sumatra. Their understanding of religious knowledge is not limited to the educational environment but also at the public. Sefriyono and Mukhibat (2018) also describe coordination between Ulama and Penghulu through a case study of efforts to prevent the religious radicalism movement in the Sungai Buluah village, Padang Pariaman [14]. According to them, the figures of Mamak ibadat (a person who has authority in the field of religion) and Mamak adat (a person who has authority in the field of adat) plays a role in managing the Surau as an effort to prevent the emergence of seeds of radicalism in the region. The interaction between these two figures shows the interrelation between religion and custom in the management of community life in West Sumatra.

In terms of public policies that fall within the scope of the political and government sectors, religious elements also get an important position. The life foundation of the Minangkabau people in the form of the philosophy of Adat Basandi Syarak, Syarak Basandi Kitabullah, has influenced the making of regulations and regulations carried out by the local government in West Sumatra. The process of policymaking by stakeholders commonly uses Adat Basandi Syarak, Syarak Basandi Kitabullah as the primary reference. Especially in recent years, Regional Regulations with elements of sharia enforced, and West Sumatra has become one of several provinces that have issued quite a several Sharia Regulation [15].

Ulama figures in West Sumatra still have a significant role to play until the present era of modernity. Syahputra (2018) argues that the relationship between ulama and the people of West Sumatra today categorized into the third wave of interaction between Muslim intellectuals and the public [16]. The first wave is coloured by direct communication through surau, madrasah, or other educational institutions. The second wave describes the relationship between the two of them with mass media intermediaries, such as newspapers, magazines, television and radio. Meanwhile, on this day, the third wave, interactions are carried out through social media. Despite this, the first and second wave schemes have continued to this day. It concluded that ulama in West Sumatra have an essential role in the wider community. Ulama are involved not only in aspects of religious life but also in other fields such as social, political and governmental. The function of Ulama in West Sumatra strengthened by the basic life principles of the community, namely Adat Basandi Syarak, Syarak Basandi Kitabullah and the majority of the population who adhere to Islam.

\section{ULAMA AS NORM ENTREPRENEUR OF NEW NORMAL NORM}

According to Finnemore and Sikkink (1998), norm entrepreneur is an actor capable of attracting broad public attention to an issue that is focused [17]. According to Davies \& True (2017), norm entrepreneur can refer to individuals or groups that represent the state or do not represent the country [18]. From this definition, the entrepreneurial norm can come from anywhere so that Ulama classified as norm entrepreneurs. It is because of Ulama can localize a norm. According to Acharya (2004), norm localization is an active construction process of an idea originating from outside through discourse and framing by local actors which can then be accepted by local communities in the form of beliefs, behaviours and actions [19]. He also explains that the local actor must be credible, namely that the community views the actor as having an important position and as the guardian of local values [20]. From this explanation, ulama can form community habits. Referring to Akhimmudin (2012) that ulama are religious leaders and also has authority in Surau [21]. Surau is a monumental Islamic educational institution in Minangkabau and has become a ritual and intellectual space [22]. Therefore, in the process of norm localization, ulama can play an active role.

New normal is the norm that first emerged from the WHO. This norm comes from outside, so a localization process is needed by ulama in West Sumatra society. It is essential to do to reduce the number of positive cases of Covid-19 in West Sumatra. According to Acharya (2004), these external norms need to reconstructed to fit local beliefs and practices to localized [23]. To simplify this process, according to Acharya, local actors need to redefine these norms and relate them to local norms by selecting the appropriate elements. In the context of West Sumatra, the majority of people are Muslim, so localizing this new normal norm is necessary to see its similarities with Islamic values internalized in society. In fact, in the West Sumatra Adapatasi Kebiasaan Baru (New Normal Adaptation) regional regulation, article 11, prevention of Covid-19 can be done by performing wudhu (ablution) for those who are Muslims. This 
article shows that the West Sumatra government has made efforts to localize this new normal norm. However, the socialization process for society requires ulama as civil society to translate this new norm into society.

From the interviews conducted, according to Suleman, Secretary of the West Sumatra Nahdlatul Ulama, ulama helped the government explain the urgency of the Covid-19 phenomenon from a religious point of view to the public [24]. Shofwan Karim, Chairman of Muhammadiyah West Sumatra and Member of the Advisory Council of the Indonesian Ulema Council (MUI) West Sumatra, also added that the socialization of this new normal norm to the public could be done by linking it to worship behaviour. Because according to Shofwan, this new normal concept is not a new norm. Therefore, in its dissemination, it is necessary to link this new normal idea with ideas that are familiar to the community. Shofwan gave an example with wudhu, which is an obligatory activity performed by a Muslim before performing prayers. The essence of wudhu is the activity of purifying oneself, and it is done at least five times a day by a Muslim [25]. Based on this example, the wudhu habit has in common with the new normal norm, namely the process of maintaining cleanliness through washing hands. Also, this example proves that there is a process of redefining the new norms that want to be localized.

The ulama try to convince the public so that they comply with the new normal norm. Ulama frames the idea of new normal through discourses related to the verses of the Al-Quran, Hadith, and the stories of the prophets conveyed in lectures. Regarding the implementation of shalat berjamaah (congregational prayers) in pandemic conditions, some changes have occurred. As a rule, prayers performed in a close and straight line. However, today's pandemic requires physical distancing between one and another. Of course, these ideas will go against existing habits. Many people ignore this appeal so that houses of worship become a new cluster in the spread of Covid-19 [26]. It shows that there is a contestation of ideas in the acceptance of a norm that exists in society.

In responding to this difference of opinion, Ulama can reconcile by providing views from the religious aspect. Shofwan argues that spacing the prayer shafts does not break the congregational prayers [27]. According to Nasir (2020) that the world condition due to a pandemic categorized as an emergency. So, Nasir explained that in fiqh principles, an emergency allows something that is forbidden and rejects danger takes precedence over taking benefits. The public can understand such an explanation if it delivers by a credible actor such as an Ulama. Cooperating with Ulama in this context is very important because ulama are one of the social capitals of Indonesia and especially in West Sumatra.

\section{CONCLUSION}

Covid-19 has become a problem at the global level. Because this virus has spread throughout the country and joint efforts are needed to overcome this health problem. Indonesia has even declared this health problem a national disaster. Months have passed; this virus has not been able to break the chain. Many regions, including West Sumatra, then adopted the new normal as a way to adapt life to today's world conditions. However, this adoption has only worsened the conditions for the spread of the virus. It marked by an increase in the number of positive victims.

To support the implementation of the new normal, the West Sumatra government has passed regulations regarding the obligation to comply with health protocols. This rule is a form of accustoming behaviour in a coercive way. In order to maximize this adaptation, a credible local actor, namely Ulama, is needed. Through the Ulama, new normal, which is a norm that comes from outside redefined through a process of framing using Islamic values that are embraced by the majority of the people of West Sumatra. By using the similarity of foreign norms and existing norms, it is easier for people to understand and comply with this new normal. Ulama have advantages because, in West Sumatra, their position is not only as a religious leader but also has a responsibility to educate the public. Besides, Ulama has an emotional closeness with society so that they can adjust their means of conveying this new norm to society. Therefore, collaborating with Ulama is the right choice for the government to limit the spread of the Covid-19 virus in West Sumatra.

\section{AUTHORS' CONTRIBUTIONS}

All of this author listed has contribution to this paper.

\section{ACKNOWLEDGMENTS}

This paper is supported by the Social and Political Sciences Faculty of Universitas Andalas through the Research Grant Fund provided by the faculty in 2020 .

\section{REFERENCES}

[1] Indonesian President's Speech : Perkembangan Terkini Penanganan dan Pencegahan Penyebaran Virus Korona di Indonesia (Update of Corona Virus Prevention in Indonesia), (2020, 2 March), in Istana Merdeka, https://setkab.go.id/perkembangan-terkinipenanganan-dan-pencegahanpenyebaran-virus- 
korona-di-indonesia-2-maret-2020-di-berandabelakang-istanamerdeka-provinsi-dki-jakarta/, accessed May 2, 2020

[2] H. K. N. Sumartiningyas, Apa itu New Normal? Presiden Jokowi Sebut Hidup Berdamai dengan Covid-19, Kompas (2020, 26 May), https://www.kompas.com/sains/read/2020/05/26/16 3200023/apa-itu-new-normalpresiden-jokowisebut-hidup-berdamai-dengan-covid-19?page=all, accessed June 15, 2020

[3] Data Pantauan Covid-19 Sumatera Barat (Update of Covid 19 cases in West Sumatera), https://corona.sumbarprov.go.id/details/index_mast er_corona, accessed on October 13, 2020

[4] D.P. Salim \& L. Kryati. Politik Pendidikan Agama dan Perubahan Prilaku Di Sumatera Barat. ElHekam: Jurnal Studi Keislaman, 2.(1), 2018: 5160.

[5] I. Istiqamatunnisak, Pengaruh Bahasa Melayu terhadap Kesusastraan Aceh Ditinjau dari Naskah Akhbār al-Karīm. Manuskripta, 2(1), 2012: 1-31.

[6] J. Kampai, Sumbar Lanjutkan PSBB Tahap III hingga 7 juni, Kecuali Bukittinggi (West Sumatra continue LSSR phase III until June 7, except Bukittinggi), DetikNews, (2020, 28 May), https://news.detik.com/berita/d-5032381/sumbarlanjutkan-psbb-tahap-iii-hingga-7-juni-kecualibukittinggi/2, accessed October 13, 2020

[7] WHO Director-General's opening remarks at the media briefing on COVID-19 - 22 April 2020, https://www.who.int/dg/speeches/detail/whodirector-general-s-opening-remarks-at-the-mediabriefing-on-covid-19--22-april-2020, accessed October 13, 2020

[8] Data Pantauan Covid-19 Sumatera Barat (Update of Covid 19 cases in West Sumatera), https://corona.sumbarprov.go.id/details/index_mast er_corona, accessed October 13, 2020

[9] F.A. Burhan, Pakai Istilah New Normal, Masyarakat Justru Langgar Protokol Covid-19, Katadata, (2020, July 11), https://katadata.co.id/febrinaiskana/berita/5f099ac5 89ca7/pakai-istilah-new-normal-masyarakat-justrulanggar-protokol-covid-19, accessed October 13, 2020)

[10] F.A. Burhan, 2020

[11] West Sumatra Province of Statistic Center, Provinsi Sumatera Barat dalam Angka 2020.

[12] L. Zamzami, et al. Kearifan Budaya Lokal Masyarakat Maritim Untuk Upaya Mitigasi
Bencana di Sumatera Barat. Jurnal Antropologi: Isu-Isu Sosial Budaya, 16(1), 2014: 37-48.

[13] M. Kosim, Tradisi Madrasah Tarbiyah Islamiyah di Sumatera Barat. At-tarbiyah 4(1), 2013: 21-45

[14] Sefriyono dan Mukhibat, Preventing Religious Radicalism Based on Local Wisdom: Interrelation of Tarekat, Adat, and Local Authority in Padang Pariaman, West Sumatera, Indonesia. SOSIOHUMANIKA: Jurnal Pendidikan Sains Sosial dan Kemanusiaan 11(1), 2018: 1-18

[15] Zulfadli, D. Anggraini, dan M. Fajri, From Formalization of Sharia to Islamic Conservatism: The Post Reform of Islamic Movement Phenomena in West Sumatera. Al'Araf Jurnal Pemikiran Islam dan Filsafat 17 (1), 2020: 1-24

[16] I. Syahputra, New Media, New Relations: Cyberstalking on Social Media in the Interaction of Muslim Scholars and the Public in West Sumatra, Indonesia. Jurnal Komunikasi: Malaysian Journal of Communication 34 (1), 2018: 153-169

[17] M. Finnemore, \& K. Sikkink, International norm dynamics and political change. International organization, 52(4), (1998), 887-917

[18] S. E. Davies, \& J. True, Norm entrepreneurship in foreign policy: William Hague and the prevention of sexual violence in conflict. Foreign Policy Analysis, 13(3), 2017: 701-721

[19] A. Acharya, How ideas spread: Whose norms matter? Norm localization and institutional change in Asian regionalism. International organization, 58(2), 2004: 239-275.

[20] A. Acharya, 2004, p.248

[21] Y. Akhimuddin, "Naskah [Asal Khilaf Bilangan Taqwim]: Relasi Ulama-Umara di Minangkabau Abad ke-17 dalam Penetapan Awal Ramadan." Manuskripta 2(1) 2012: 79-101.

[22] S. Hanani,. "Tradisi Ulama Transformatif Minangkabau dalam Membangun Pendidikan Karakteristik Berbasis Responsif Teologis dan Kontribusinya terhadap Penguatan Moralitas." Sosial Budaya 12(2), 2016: 191-202.

[23] A. Acharya, 2004, p.251

[24] Interview with Suleman, Secretary of Nahdlatul Ulama in West Sumatra on October 5, 2020

[25] Interview with Shofwan Karim, Chair of Muhammadiyah in West Sumatra and Board of Advisory of Majelis Ulama Indonesia on October 15,2020 
[26] S.K.N.Aula, Peran Tokoh Agama Dalam Memutus Rantai Pandemi Covid-19 Di Media Online Indonesia, Living Islam: Journal of Islamic Discourses, 3(1), 2020: 125-148

[27] Interview with Shofwan Karim, Chair of Muhammadiyah in West Sumatra and Board of Advisory of Majelis Ulama Indonesia on October 15,2020

[28] A. Nasir. "Social Distancing Dalam Saf Salat Berjamaah (Perbandingan Ulama dalam Mazhab)." Mazahibuna 2(1), 2020: 29-36 